Marquette University

e-Publications@Marquette

College of Nursing Faculty Research and

Publications

Nursing, College of

7-1-2017

Risk and Protective Factors in the Lives of Caregivers of Persons With Autism: Caregivers' Perspectives

Abir K. Bekhet

Marquette University, abir.bekhet@marquette.edu

Denise M. Matel-Anderson

Marquette University

This is the peer reviewed version of an article that appeared in Perspectives in Psychiatric Care, Vol. 53 No. 3 (2017). Published in final form here: DOI. This article may be used for non-commercial purposes in accordance With Wiley Terms and Conditions for self-archiving. (C) 2017 John Wiley \& Sons, Inc. Used with permission. 


\title{
Risk and Protective Factors in the Lives of Caregivers of Persons With Autism: Caregivers' Perspectives
}

\author{
Abir K. Bekhet PhD, RN, HSMI \\ College of Nursing, Marquette University \\ Milwaukee, WI \\ Denise Matel-Anderson APNP, RN \\ College of Nursing, Marquette University \\ Milwaukee, WI
}

\begin{abstract}
PURPOSE: The purpose of this descriptive exploratory study is to understand the experience of being a caregiver of a person with autism spectrum disorder (ASD) in the light of the resilience theory.
\end{abstract}

METHODS: Qualitative data were collected as a part of a larger quantitative study. Ninety-three caregivers completed this qualitative study and responded to the two open-ended questions. In the parent study, subjects were recruited by convenience sampling from the Interactive ASD Network (IAN).

FINDINGS: The identified categories appeared to reflect three distinct categories consistent with the resilience theory, labeled as follows: risk factors, protective factors, and overlapping factors. 
PRACTICE IMPLICATIONS: These findings help to inform the planning of tailored interventions to enhance caregivers' resilience.

In the United States, one in 68 children is affected by autism spectrum disorder (ASD; Centers for Disease Control and Prevention $[C D C], \underline{2015}$ ). This current projection is approximately $30 \%$ higher than those reported in 2012 (CDC, 2015; National Autism Association, 2014). ASD is a lifelong developmental disorder that begins before age 3 and affects the child's learning, thinking, social interactions, and problem-solving abilities (American Psychiatric Association [APA], 2000; CDC, 2015). Research has shown that caregivers of children with ASD experience poorer health and an increase in reported stress, anxiety, depression, and physical health problems than parents of children with typical development (Bekhet, 2014; Estes et al., 2013; Huang et al., 2014; Lovell, Moss, \& Wetherell, 2012a). Foody, James, and Leader (2014) found a dysregulation in cortisol levels in mothers of children with ASD (Foody et al., 2014). Similarly, Lovell et al. (2012a) found an increase in cortisol levels in parents of children with ASD when compared with parents with typical development, indicating high levels of stress among ASD caregivers (Lovell et al., 2012a, 2012b). In Jordan, a quantitative study conducted by Dardas and Ahmad (2014) examined the relationship between parents' characteristics and the coping strategies used in a sample of 184 Jordanian parents of persons with ASD. The results indicated that parents who have higher incomes, use diverse problem-solving strategies, and exhibit less escape-avoidance tended to report lower stress and higher quality of life. On the other hand, in Taiwan, another quantitative study indicated that caregivers of children with mild or moderate autistic behavior problems perceived lower parenting stress as compared with those of children with less-severe autistic problems (Huang et al., 2014). Their results also indicated that prosocial behaviors and conduct problems predicted stress in the parent-child relationship and child-related stress (Huang et al., 2014). In Iran, mothers of children with ASD $(n=58)$ had significantly higher scores than fathers of children with ASD $(n=45)$ on measures of stress, indicating higher levels of stress. Also, their results indicated that poorer health was associated with lower educational levels of the parents and more behavioral problems with the child (Samadi \& McConkey, 2014).

[Perspectives in Psychiatric care, Vol 53, No. 3 (July 2017): pg. 199-207. DOI. This article is @ [Wiley] and permission has been granted for this version to appear in e-Publications@Marquette. [Wiley] does not grant permission for this article to be further copied/distributed or hosted elsewhere without the express permission from [Wiley].] 
Previous qualitative studies have looked at the experience of caregiving but have not directly identified risk factors, protective factors, and overlapping factors in the light of the resilience theory from the perspective of the ASD caregivers, as proposed in this study. For example, Zhou and Yi (2014), in their qualitative research, studied parenting styles among parents with ASD in China. Their results indicated that the ASD caregivers' own emotions have an impact on the behavior of children with ASD (Zhou \& Yi, 2014). Another qualitative study with seven mothers of ASD children in Australia found that the mothers were challenged by the demands of their multiple roles and they were torn between the paradox of accepting their child for who they were and their desires of a typical growth and development for their children (Safe, Joosten, \& Molineuz, 2012). In addition, ASD sibling relationships have received attention in recent years in England. For example, the qualitative study conducted by Tozer, Atkin, and Wenham (2013) indicated that adult siblings of persons with ASD contributed to meaningful caring relationships and service delivery to their siblings who have ASD diagnosis (Tozer et al., 2013). In Ontario, Fletcher, Markoulakis, and Bryden (2012) examined the costs of caring for a child with ASD from the perspectives of eight mothers. The results indicated that all family members were affected by the ASD child and the costs of caring involved the financial, social, and health aspects and overall family life (Fletcher et al., 2012). Another qualitative study with 16 Australian older parents with a child diagnosed with ASD investigated the augmentative and alternative communication experiences and their impacts on caregivers' gratification and/or stress. Results indicated that the quality of communication has tremendous effects on both caregivers' stress and gratification (Hines, Balandin, \& Togher, 2011).

The purpose of this descriptive exploratory qualitative study is to identify risk factors, protective factors, and overlapping factors in the light of resilience theory from the perspective of the ASD American caregivers. In identifying these factors, using the resiliency theory, interventions can target specific areas to build on protective factors and to reduce risk factors for this population.

\section{Theoretical Framework}

[Perspectives in Psychiatric care, Vol 53, No. 3 (July 2017): pg. 199-207. DOI. This article is @ [Wiley] and permission has been granted for this version to appear in e-Publications@Marquette. [Wiley] does not grant permission for this article to be further copied/distributed or hosted elsewhere without the express permission from [Wiley].] 
The current study used resilience theory as a guided theoretical framework that proposes that resilience is the interplay between risk factors and protective factors in the face of adversity (Luthar, Cicchetti, \& Becker, 2000). Risk factors are factors that influence a person's coping, predispose them to stress, and can lead to physical and psychological health problems (Bekhet, Johnson, \& Zauszniewski, 2012a, 2012b; Greene, Galambos, \& Lee, 2003; Smith-Osborne, 2007). Protective factors, on the other hand, can buffer the effects of risk factors, decrease its influence, and prevent the occurrence of physical and health problems and can lead to positive health outcomes (Bekhet et al., 2012a, 2012b; Rutter, 1987; Zauszniewski, Bekhet, \& Suresky, 2015). The interplay between the risk and protective factors indicated the levels of resilience in caregivers.

\section{Method}

Qualitative data for this study were collected to explore what it is like to be a caregiver of a person with ASD. The qualitative data for this analysis were collected as a part of a larger quantitative study that involved 95 ASD caregivers. Qualitative data in this study answered two research questions: "What is it like to be a caregiver of a person with ASD?" and "Is there anything else that you want us to know?" Ninety-three caregivers of persons with ASD completed the two openended questions; the other two caregivers did not respond to these two questions. The two questions were part of larger written questionnaires and were collected through SurveyMonkey. In the parent study, the Institutional Review Board (IRB) approval was obtained and subjects were recruited by convenience sampling from the Interactive ASD Network (IAN). The IAN directed potential participants to the Internet website (www.surveymonkey.com) where a consent form and a link to the study questionnaires were housed (Bekhet et al., 2012a). The purpose of the parent study was to investigate the mediating effects of caregivers' positive cognition as a protective factor on the relationship between caregivers' burden as a risk factor and caregivers' resourcefulness as an indicator of resilience among caregivers of persons with ASD (Bekhet et al., 2012a).

\section{Data Analysis}

[Perspectives in Psychiatric care, Vol 53, No. 3 (July 2017): pg. 199-207. DOI. This article is (C) [Wiley] and permission has been granted for this version to appear in e-Publications@Marquette. [Wiley] does not grant permission for this article to be further copied/distributed or hosted elsewhere without the express permission from [Wiley].] 
The two researchers used content analysis to study the categories across caregivers. Creating categories is the essential feature of qualitative content analysis. A category is a group of content that shares a commonality (Graneheim \& Lundman, 2004; Krippendorff, 1980). Content analysis consists of the process of reading the transcripts, coding the data, and identifying the categories in each caregiver's response and then re-reading the responses to find out congruent categories across caregivers (Graneheim \& Lundman, 2004). The credibility of the data was enhanced by independent coding of the data by the researcher (A.K.B.) and research assistant (D.M-A.), who individually performed data analysis of the caregivers' responses, highlighting text in each caregiver's response and identifying the categories and subcategories. To ensure the trustworthiness of findings, the two researchers met in person and compared the interpretations of the responses until they reached a consensus on the categories and subcategories from the parents' responses as an iterative process (Glaser, 1992; Struebert \& Carpenter, 1999).

Credibility and truthfulness of the current research are also enhanced through the use of the ASD caregivers' quotations that reflect the accurate descriptions of caregivers' experiences and based on the reality that the caregivers who had those experiences immediately recognized them from those descriptions or through interpretations of their own (Guba \& Lincoln, 1989). Also, given the fact that these qualitative study findings fit contexts outside of the current research situation and are meaningful, "fittingness," which is equal to external validity in quantitative research, was achieved. Saturation was also achieved as there was redundancy and as no new themes arose from the caregivers' experiences (Guba \& Lincoln, 1989).

\section{Results}

\section{Demographics}

The ages of caregivers ranged from 23 to 77 years $(M=42.8$, $S D=7.9)$. A total of $96.8 \%$ of the caregivers were females $(n=92)$ and $3.2 \%$ were males $(n=3)$. The great majority of the caregivers

[Perspectives in Psychiatric care, Vol 53, No. 3 (July 2017): pg. 199-207. DOI. This article is @ [Wiley] and permission has been granted for this version to appear in e-Publications@Marquette. [Wiley] does not grant permission for this article to be further copied/distributed or hosted elsewhere without the express permission from [Wiley].] 
( $n=88$ ) were Caucasian, representing $92.6 \%$ of the total sample (Bekhet et al., 2012a).

\section{Categories}

Three distinct categories consistent with the resilience theory had been identified, labeled as risk factors, protective factors, and overlapping factors.

\section{Category 1: Risk Factors}

The first category, labeled risk factors, included the following subcategories: "stressful and out of control," "challenging," "overwhelming/draining," "unpredictability and worry about the future," "child's challenging behaviors and emotions," "negative responses of others/lack of public awareness," "lack of resources," and "financial concerns" (Table $\underline{1}$ ).

Table 1. Summary of Categories Expressed by Caregivers of Persons With ASD

\begin{tabular}{|c|c|c|}
\hline $\begin{array}{l}\text { Category } \\
\text { or factor }\end{array}$ & Subcategory & Example \\
\hline \multirow[t]{4}{*}{$\begin{array}{l}\text { 1. Risk } \\
\text { factors }\end{array}$} & $\begin{array}{l}\text { a. Stressful and out of } \\
\text { control }\end{array}$ & $\begin{array}{l}\text { "It is extremely stressful. It } \\
\text { is like walking on egg shells } \\
\text { all of the time ... some days I } \\
\text { feel completely out of } \\
\text { control." }\end{array}$ \\
\hline & b. Challenging & "It is definitely challenging \\
\hline & c. Overwhelming/draining & $\begin{array}{l}\text { "It is incredibly } \\
\text { overwhelming and a daily } \\
\text { drain on me." }\end{array}$ \\
\hline & $\begin{array}{l}\text { d. Unpredictability and } \\
\text { worry about the future }\end{array}$ & $\begin{array}{l}\text { "It is like taking an exam. } \\
\text { wondering how things will } \\
\text { go. It is like constantly being } \\
\text { stressed about now and the } \\
\text { future." }\end{array}$ \\
\hline
\end{tabular}

[Perspectives in Psychiatric care, Vol 53, No. 3 (July 2017): pg. 199-207. DOI. This article is (C [Wiley] and permission has been granted for this version to appear in e-Publications@Marquette. [Wiley] does not grant permission for this article to be further copied/distributed or hosted elsewhere without the express permission from [Wiley].] 


\begin{tabular}{|c|c|c|}
\hline $\begin{array}{l}\text { Category } \\
\text { or factor }\end{array}$ & Subcategory & Example \\
\hline & $\begin{array}{l}\text { e. Child's challenging } \\
\text { behaviors and emotions }\end{array}$ & $\begin{array}{l}\text { "My son is also a fire starter } \\
\text { and an elopement risk." }\end{array}$ \\
\hline & $\begin{array}{l}\text { f. Negative responses of } \\
\text { others/lack of public } \\
\text { awareness }\end{array}$ & $\begin{array}{l}\text { "The most challenging part of } \\
\text { caring for my son with ASD } \\
\text { is dealing with the public and } \\
\text { their perceptions of him." }\end{array}$ \\
\hline & g. Lack of resources & $\begin{array}{l}\text { "There are not of enough } \\
\text { resources where I live for } \\
\text { him and I feel like I have to } \\
\text { beat my head against brick } \\
\text { walls to get him into services } \\
\text { that are available." }\end{array}$ \\
\hline & h. Financial concerns & $\begin{array}{l}\text { "Financially it is challenging } \\
\text { since social skills therapy } \\
\text { and individual therapy is } \\
\text { expensive." }\end{array}$ \\
\hline \begin{tabular}{|l}
2. \\
Protective \\
factors
\end{tabular} & $\begin{array}{l}\text { a. Rewarding and serving } \\
\text { a purpose }\end{array}$ & $\begin{array}{l}\text { "It's so rewarding. My son is } \\
5 \text { and he's the light of my } \\
\text { life." }\end{array}$ \\
\hline & b. Love of the child & $\begin{array}{l}\text { "If I didn't love him so very } \\
\text { much, I would never be able } \\
\text { to sustain the daily effort and } \\
\text { remain calm." }\end{array}$ \\
\hline & \begin{tabular}{|l} 
c. Celebrating small \\
accomplishments
\end{tabular} & $\begin{array}{l}\text { "The smallest triumph can be } \\
\text { huge and a reason for } \\
\text { celebration." }\end{array}$ \\
\hline & d. Learning experience & $\begin{array}{l}\text { "Over the years I believe } \\
\text { that I have earned honorary } \\
\text { degrees in education, } \\
\text { chemistry and medicine." }\end{array}$ \\
\hline & $\begin{array}{l}\text { e. Acceptance and care } \\
\text { become easier }\end{array}$ & $\begin{array}{l}\text { "We also had to accept our } \\
\text { son for who he is, we owed } \\
\text { him that, to be happy that } \\
\text { this wonderful boy is in our } \\
\text { lives." }\end{array}$ \\
\hline
\end{tabular}

[Perspectives in Psychiatric care, Vol 53, No. 3 (July 2017): pg. 199-207. DOI. This article is @ [Wiley] and permission has been granted for this version to appear in e-Publications@Marquette. [Wiley] does not grant permission for this article to be further copied/distributed or hosted elsewhere without the express permission from [Wiley].] 


\begin{tabular}{||l||l|l||}
\hline $\begin{array}{l}\text { Category } \\
\text { or factor }\end{array}$ & \multicolumn{1}{|c|}{ Subcategory } & \multicolumn{1}{|c||}{ Example } \\
\hline \hline & f. Family togetherness & $\begin{array}{l}\text { "In some ways it has brought } \\
\text { our entire family closer } \\
\text { together." }\end{array}$ \\
\hline $\begin{array}{l}\text { t. } \\
\text { Overlapped } \\
\text { factors }\end{array}$ & $\begin{array}{l}\text { a. Challenging } \\
\text { (Frustrating) and } \\
\text { rewarding }\end{array}$ & $\begin{array}{l}\text { "A challenging but rewarding } \\
\text { experience ..." }\end{array}$ \\
\hline \hline & b. Mixed (overlapping) \\
emotions & $\begin{array}{l}\text { "It is heartbreaking, } \\
\text { uplifting, joyful, worrisome, } \\
\text { mundane ... and an } \\
\text { adventure every day." }\end{array}$ \\
\hline
\end{tabular}

\section{Subcategory 1: Stressful and Out of Control}

The most prevalent risk factor for caregivers of children with ASD identified in this study was stressful and out of control.

Approximately, one third of the study participants $(n=30)$ identified stressful and out of control as a risk factor. The following are examples provided by two caregivers. One caregiver described her caregiving experience as: "Very stressful. Yet I thrive on stress, but it takes it's [its] toll on my body. I like to be in control of things, so feeling out of control gives me anxiety and since i [I] have very little control over my life it can become overwhelming." Another caregiver stated: "It is extremely stressful. It is like walking on egg shells all of the time. For me, it is very unrewarding. Some days I work really hard at taking care of my son and I tell myself to stay calm, but some days I feel completely out of control. A lot of times I just want to sleep and not deal with the situation. I feel like a failure as a parent, especially to my older, normal functioning child." Another caregiver explained the causes of her stress by pointing out that she has no time to enjoy activities by stating, "It also feels like I should always be working, working, working with my child so that he never has time to stim. Life revolves around autism, and nothing else. I lost my sense of self and normalcy. It is also about grieving what was supposed to be ... a normal, simple life where you can go to the park, have a picnic, and have fun. All of these 'normal' activities just cause a lot stress."

[Perspectives in Psychiatric care, Vol 53, No. 3 (July 2017): pg. 199-207. DOI. This article is (C) [Wiley] and permission has been granted for this version to appear in e-Publications@Marquette. [Wiley] does not grant permission for this article to be further copied/distributed or hosted elsewhere without the express permission from [Wiley].] 


\section{Subcategory 2: Challenging}

The data that emerged from the caregivers' responses fit under this subcategory. A total of $22.6 \%$ of the caregivers $(n=21)$ described their caregiving experiences as challenging. For example, one caregiver stated "It is definitely challenging. I feel overwhelmed sometimes." Another caregiver pointed out that "There are challenges, but life is challenging. It is all in how you view your circumstances." Other caregivers went into more detail describing their challenges in caring for a child diagnosed with ASD and pointed out some of the reasons. For instance, one caregiver shared her experience by saying "It is challenging when your [you are] trying to help the person perceive others point of view and respect others. They are rather variable and hard to predict. In one setting they will be appropriate and another will be meltdown time." Another caregiver said, "Very challenging. Having to constantly reassure him that he is a good person and that if he is himself he will make friends and people will like him. Sometimes it is very difficult to answer his questions."

\section{Subcategory 3: Overwhelming/Draining}

The data that emerged from the caregivers' responses fit under this subcategory. Sixteen caregivers (17.2\%) indicated that caregiving is overwhelming and draining. Comments from caregivers included, "It is incredibly overwhelming and a daily drain on me. I love my son with every fiber of my being"; "Overwhelming and endless ... pretty much takes over my whole life"; and "It is overwhelming. Kind of like being in a hurdle race ... you're moving as fast as you can to keep ahead of the problems, but something ALWAYS comes up again!"

Others went further in explaining the reasons of being overwhelmed and their feelings. One example provided by a mother was, "As a single mother of three children it is difficult to focus on the needs of one child over the others. I feel completely drained by midafternoon/early evening." Another caregiver stated: "It is overwhelming. More than I could ever imagined ... you always have to 'fight' people as you go. It is a very big challenge and affects every aspect of my life!" A third caregiver explained, "An incredible amount of responsibility. No time for completing chores, running errands,

[Perspectives in Psychiatric care, Vol 53, No. 3 (July 2017): pg. 199-207. DOI. This article is @ [Wiley] and permission has been granted for this version to appear in e-Publications@Marquette. [Wiley] does not grant permission for this article to be further copied/distributed or hosted elsewhere without the express permission from [Wiley].] 
grocery shopping, exercising, cooking, preparing meals, much less time for leisure. Easily stressed out, overwhelmed."

\section{Subcategory 4: Unpredictability and Worry About the Future}

The data that emerged from the caregivers' responses fit under this subcategory. Sixteen caregivers (17.2\%) mentioned that part of the caregiving experience is unpredictability and worry about the future. One caregiver pointed out that unpredictability makes her stressed out by saying, "This unpredictability makes me stressed. I am always prepared for the worse but usually things are OK. If I had a crystal ball I could enjoy group functions and social occasions much more." Another caregiver shared the reasons for her fears and worries by stating, "It breaks my heart to pieces just to think about her future after I'm gone. She is almost 12 years old and not toilet trained. She is over $100 \mathrm{lbs} .$, just $10 \mathrm{lbs}$. less than me. I fear that I may not be able to take care of her at some point in the future due to her being bigger than me and stronger than me. She is aggressive at times." Another caregiver felt that this unpredictability equates with taking an exam by saying, "It is like taking an exam. Always worrying and wondering how things will go. It is like constantly being stressed about now and the future. It is never-ending." Three other caregivers shared their experiences and worries about the future by saying: (a) "My biggest fear is that I will not be able to prepare my son for the future. When we are gone ... I don't want him to end up alone and misunderstood. He has a lot of wonderful qualities ... but they are easily missed," (b) "I worry about his future because he will not attend college, and does not have job skills or the attention to do a job well. Fortunately, we are not strapped financially, so he will be able to live with us. I do feel sad sometimes because I don't see us able to enjoy retirement as we would like," and (c) "I spend many hours worrying about how their lives will end up, and what kind of future they will have. I just want the world to accept them so they can be safe and happy."

\section{Subcategory 5: Child's Challenging Behaviors and Emotions}

[Perspectives in Psychiatric care, Vol 53, No. 3 (July 2017): pg. 199-207. DOI. This article is @ [Wiley] and permission has been granted for this version to appear in e-Publications@Marquette. [Wiley] does not grant permission for this article to be further copied/distributed or hosted elsewhere without the express permission from [Wiley].] 
Seventeen caregivers (18.3\%) shared their experiences of having a child with challenging behavior, the struggles they have with them, and their impacts on the family's life. One mother shared her experiences with her son. She explained that her son is a fire starter and she described the effects of his challenging behavior not only on her but also on her other kids by stating: "My son is also a fire starter and an elopement risk. We've had digital locks INSIDE our house and constant fear that he will discover that the toaster can set things on fire. The stress can be very high, as we've already lost one home to his fires. Its hard on my other kids too. Medication has helped very much with his impulsive behaviors, and the locks are normal ones now (he's 11 1/2 now), but the tension never leaves. I wanted to have him places in residential treatment to keep my other children (and him, of course) safe, but no one would take him due to fire starting."

Another caregiver described her son's violent behavior and the difficulty she has, given the fact that she is a single mother, by saying: "It is difficult because it's just me taking care of my son alone, no help or breaks. He's with me 24/7 unless he's in school. It wouldn't be so bad if my son didn't have mood swings and try to bully me. He can get aggressively violent at times. When he gets something on his mind he cannot let it go. I've set through a 2-3 hour violent rant because he can't seem to stop talking about the subject. He gets threatening and hard to calm down."

A third caregiver described her child's challenging behaviors and emotions and their impacts on her in terms of being depressed and unable to enjoy life by stating: "I know all kids with autism are all very different, but my son is very angry and ragefull. We can't go anywhere or do anything as a family because we never know how he will behave. I feel like we are in a prison or were dealt a death sentence by having him. I often wonder what my life would have been like if we didn't have him. My husband and I have become such different people than I ever imagined we would. We are both very depressed. I feel like all I do is think about my son and what happened or what is going to happen or what help I can get for him. There is just nothing happy about our lives." Another two experiences provided by two caregivers included, "It's getting harder as my son gets older. He's bigger than me and has anger meltdowns" and "He can have tantrums that leave

[Perspectives in Psychiatric care, Vol 53, No. 3 (July 2017): pg. 199-207. DOI. This article is @ [Wiley] and permission has been granted for this version to appear in e-Publications@Marquette. [Wiley] does not grant permission for this article to be further copied/distributed or hosted elsewhere without the express permission from [Wiley].] 
me very short tempered and at times I fear for my ability to be calm in front of him, and this leaves me feeling helpless."

\section{Subcategory 6: Negative Responses of Others/Lack of Public Awareness}

Another concern expressed by 12 caregivers of persons with ASD (12.9\%) is negative responses of others/lack of public awareness. One caregiver pointed out that people often misinterpret the behavior of her child as "undisciplined" and this is due to the lack of public awareness. She shared her experiences by saying, "The most challenging part of caring for my son with ASD is dealing with the public and their perceptions of him. Most often, people who do not know us or anything about ASD (including school administration) think that he is an undisciplined, unruly child."

Another caregiver shared their experiences and feelings about how other people avoid their grandson after being diagnosed with ASD as if he is "contagious"; she further pointed out the fact of the lack of public awareness by stating, "I don't think anyone has a clue as to what it is like to raise an autistic child unless they have a child with autism. I don't think there are enough support groups for parents and I don't think the public is very educated about how to interact with a family who has a child with a disability. It is amazing the number of friends and neighbors who act like Autism is a forbidden subject and that the child is now too contagious for their kids to be around neighbors who thought nothing of asking us to babysit their kids for hours at a time but disappeared once our grandson was diagnosed with Autism."

Four caregivers described the negative responses of others/lack of public awareness by saying (a) "One difficulty are the stares from strangers that occasionally happens because of ignorance," (b) "It's hard most of the time, when you go out in market and you have to endure those people look at you and your child like they see alien or something. Sometimes I am sick and tired of explaining my situation to others," (c) "The real stress placed on me as a caregiver isn't so much from care for my child, but from the negative attitude and opinion of others who can't cope with an individual who is simply

[Perspectives in Psychiatric care, Vol 53, No. 3 (July 2017): pg. 199-207. DOI. This article is @ [Wiley] and permission has been granted for this version to appear in e-Publications@Marquette. [Wiley] does not grant permission for this article to be further copied/distributed or hosted elsewhere without the express permission from [Wiley].] 
different than others," and "Life is just hard because public awareness about Autism is not widespread to the point the general public doesn't contribute to the bad feelings I feel as a caregiver ... embarrassment, lack of control, bad parent."

\section{Subcategory 7: Lack of Resources}

Another concern expressed by 10 caregivers of persons with ASD $(10.8 \%)$ is lack of resources. One caregiver described lack of resources as: "There are not of enough resources where I live for him and I feel like I have to beat my head against brick walls to get him into services that are available. He is of age now, and it is a constant battle to help him and keep him on track and raise my daughter, too." Another caregiver shared her wishes of having more "nontraditional medical supplies" by saying, "There needs to be more resources available. It is hard to afford equipment such as safety things like fenced yard, security, alarms more non traditional medical supplies." Other caregivers expressed their wishes of having accessible day programs and/or camps especially during the summer. One caregiver stated, "There are so few resources in the community that I am in that summers are very difficult. There are no camp or day programs that are capable of meeting his needs in our area. I have to work, and I know he isn't getting adequate care and attention to meet his special needs that could help him grow and practice life skills to allow him to learn to adapt in the non-autistic world." Another caregiver expressed her frustration regarding lack of help and programs available to persons with autism, "I wish science could figure autism out. How can we grow humans in a lab and put people on the moon and not be able to help people who have autism? There need to be more programs available in all areas for all people." Another caregiver expressed the difficulty younger parents might experience due to limited resources, "Navigating all the information on ASD is overwhelming ... Luckily, I am an 'older' parent with adequate resources and understanding of the literature I research. I can only imagine how much more difficult it must be for younger parents and families with severely limited resources."

\section{Subcategory 8: Financial Concerns}

[Perspectives in Psychiatric care, Vol 53, No. 3 (July 2017): pg. 199-207. DOI. This article is @ [Wiley] and permission has been granted for this version to appear in e-Publications@Marquette. [Wiley] does not grant permission for this article to be further copied/distributed or hosted elsewhere without the express permission from [Wiley].] 
Financial concerns was another subcategory expressed by three caregivers of persons with ASD. The following includes examples from three caregivers who shared their thoughts and concerns: (a) "Financially it is challenging since social skills therapy and individual therapy is expensive"; (b) "There need to be laws to make insurance pay for all necessary therapy. There needs to be places that employee people to help families in the home, that we can actually afford, to help us"; and (c) "We have no money to leave. We have spent everything on our children, mortgaged and remortgaged our house. I worry the twin will not only inherit her autistic sister but will also inherit either my husband or I with a severe health issue."

\section{Protective Factors}

The second category, labeled risk factors, included the following subcategories: "rewarding and serving a purpose," "love of the child," "celebrating small accomplishments," "learning experience," "acceptance and care becoming easier," and "family togetherness" (Table 1 ).

\section{Subcategory 1: Rewarding and Serving a Purpose}

Only three caregivers were able to see their caregiving experiences as rewarding and serving a purpose. One caregiver shared her experiences of having "unexpected joyful times" and how rewarding this experience might be: "There are some unexpected joyful times when the person can be so insightful that it amazes you. And at other times, when the person shows that they have learned the tasks you taught them it can be very rewarding. "Another caregiver said, "It's so rewarding. My son is 5 and he's the light of my life."

\section{Subcategory 2: Love of the Child}

Sixteen caregivers (17.2\%) described their love of the child as a protective factor. One caregiver, who is a father of a child with ASD, describes his caregiving experience as a "gift." He stated, "I am a single father of an 11 yrs [year old] boy with autism. He lives with me all the time. He's my favorite thing in the world, a gift! I love his mind, his musical talents and his gentleness, his candid fascination with

[Perspectives in Psychiatric care, Vol 53, No. 3 (July 2017): pg. 199-207. DOI. This article is @ [Wiley] and permission has been granted for this version to appear in e-Publications@Marquette. [Wiley] does not grant permission for this article to be further copied/distributed or hosted elsewhere without the express permission from [Wiley].] 
things, his learning so many things as I watch through the years ... I have no complaints about being his dad, I love being his dad I tell him that almost every day." Another caregiver describes his caregiving experience as an amazing responsibility by saying, "It is an awesome responsibility and just when I feel I do not know if I am up for the job something amazing happens, like a huge word will be said ... or he says ... Mom, I love you!"

Another caregiver explained that her extreme love for the child was a protective factor and helped her endure the stress, "If I didn't love him so very much, I would never be able to sustain the daily effort and remain calm around him." Four caregivers expressed their love for their child by saying, (a) "Very busy! But I love him so much and it is worth it"; (b) "He has so much to give and I love him so much"; (c) "I love my daughter more than words can express and she was wanted and planned, I did everything I was suppose to [do] during pregnancy to make sure she would be healthy ... she does know I love her"; and (d) "It covers the entire spectrum of emotions. There are far more moments of joy and love than pain and frustration."

\section{Subcategory 3: Celebrating Small Accomplishments}

The data that emerged from the caregivers' responses fit under this subcategory. Twelve caregivers (12.9\%) were able to see the small accomplishments of their children as triumph and were able to describe them as a reason for celebration. Examples of caregivers' experiences are as follows: (a) "There's a lot of highs and lows. The smallest triumph can be huge and a reason for celebration"; (b) "There is also a lot of hope and joy and happiness. You notice every small bit of progress and it feels wonderful. You don't take small things for granted"; (c) "We (the family) must learn to celebrate small victories; other families do not understand that"; and (d) "Encompassing, exhausting and frustrating at times yet it is to watch new achievements and social skills emerge appropriately it is exhilarating and so worthwhile."

\section{Subcategory 4: Learning Experience}

[Perspectives in Psychiatric care, Vol 53, No. 3 (July 2017): pg. 199-207. DOI. This article is @ [Wiley] and permission has been granted for this version to appear in e-Publications@Marquette. [Wiley] does not grant permission for this article to be further copied/distributed or hosted elsewhere without the express permission from [Wiley].] 
The data that emerged from the caregivers' responses fit under the subcategory learning experience. Five caregivers described the benefits of caring for a child with ASD and they were able to describe how they grew out of this experience. One caregiver stated: "There are so many benefits as well. I have grown in so many ways that just would not have been possible if I had not had a child with autism. My son is really a beautiful person, and has shared so much with me, and taught me to see the world in different and sometimes wondrous ways. This experience has taught me patience, and humility, and perseverance, and flexibility, and especially compassion for others, and for myself. It has taught me to focus on the truly important things, and what the truly important things really are."

Another caregiver said, "Over the years I believe that I have earned honorary degrees in education, chemistry and medicine." Other caregivers mentioned that they learned something new every day. One caregiver stated, "A roller coaster ride. Always learning something new about that person, what works and what doesn't, being prepared for something unusual everyday." Another caregiver shared his caregiving experience that taught him how to be grateful, "I have learned how to be happy and grateful for every good thing he is. I have no complaints about being his dad, I love being his dad I tell him that almost every day." Finally, another caregiver stated, "I have learned many things I never would have otherwise (patients, parenting skills, etc.)."

\section{Subcategory 5: Acceptance and Care Become Easier}

Nine caregivers shared their experiences of how the acceptance of their children for who they are helped them to feel peaceful and made the care easier. One caregiver stated, "I do not feel stuck in my situation. This is a part of my life and I accept that. What I do is part of a fulfilling life. There are many joys to being a caregiver and I do not want to miss out on them because of having dwelled on the downsides of ASD. I view our situation as one that is progressive. It is forward moving and developing most of the time." Another caregiver shared her experience of the care getting easier by saying, "It gets easier as the child AND the parent get older and can communicate better." Another form of acceptance was expressed by a caregiver as a form of peace with ASD, "I made my peace with autism - life is good."

[Perspectives in Psychiatric care, Vol 53, No. 3 (July 2017): pg. 199-207. DOI. This article is @ [Wiley] and permission has been granted for this version to appear in e-Publications@Marquette. [Wiley] does not grant permission for this article to be further copied/distributed or hosted elsewhere without the express permission from [Wiley].] 
Another caregiver shared her experiences that she has forced to accept her severely autistic son but once she accepted her child for who he is, she started to appreciate the caregiving experience: "We were faced with accepting that we had a severely autistic son who had challenges that, at that time, we didn't feel prepared to face. Now that we have been successful in caring for him, we feel more hopeful that we can continue to do so. We also had to accept our son for who he is, we owed him that, to be happy that this wonderful boy is in our lives."

\section{Subcategory 6: Family Togetherness}

Family togetherness emerged from four caregivers' responses, as one caregiver stated, "In some ways it has brought our entire family closer together." Another caregiver expressed how her entire family has worked as a unit by saying: "My son is 1 of my children. We (all the kids) have always pitched in and worked as a unit, even having my son help himself \& others when he can. I tend to shelter/baby him more than the others, treating him as the youngest and they all remind me he's more capable, which they're almost always right." A third caregiver compared how hard caregiving was when her child was first diagnosed and how her family is stronger and closer now: "I look at how hard it was raising my son as a toddler when he was first diagnosed, and also having to deal with a younger sibling. But I see how far he's come and I'm so proud of our whole family for getting through everything together and we are stronger for it!"

\section{Third Category: Overlapping Factors}

The third category was overlapping factors that reflected the caregivers' descriptions of both risk and protective factors that influenced their resilience.

\section{Subcategory 1: Challenging (Frustrating) and Rewarding}

Twenty-three caregivers expressed caregiving as both challenging (risk factors) and rewarding (protective factors). One caregiver stated, (a) "A challenging but rewarding experience. I have learned a lot by having a child with autism." Another caregiver stated,

[Perspectives in Psychiatric care, Vol 53, No. 3 (July 2017): pg. 199-207. DOI. This article is @ [Wiley] and permission has been granted for this version to appear in e-Publications@Marquette. [Wiley] does not grant permission for this article to be further copied/distributed or hosted elsewhere without the express permission from [Wiley].] 
"Rewarding, exhausting, time consuming, challenging, detective work, worth all your effort to see rewards"; (b) "It can be both very frustrating and rewarding at the same time ... there are more frustrating periods than rewards"; (c) "It is the hardest but the most rewarding thing I ever thought I would have to do."

\section{Subcategory 2: Mixed (Overlapping) Emotions}

Fifteen caregivers expressed mixed emotions. Examples of caregivers overlapping emotions are as follows: (a) "It is heartbreaking, uplifting, joyful, worrisome, mundane (as with any child), and an adventure every day"; (b) "There are a lot of emotions that come into play. Especially as a parent of two. You are happy, excited, proud, when your child is able to do well or gets past something they have been working on. On the other hand when your children are having a trying day, you feel sad, overwhelmed, confused, and scared to death that once your gone what will happen to my child. Who will care and love them the way they deserve to be"; (c) "It can be difficult and emotionally tiring; however, when my child succeeds at anything, I am ecstatic."

\section{Discussion and Implications for Practice}

This is the first study that investigated the parents' experience of being a caregiver of a person with ASD with 93 caregivers of persons with ASD in the light of the resilience theory. The results from the study were consistent with the resilience theory. The caregivers in this study expressed having risk factors, protective factors, and overlapping factors. The two subcategories of the overlapping factors identified by caregivers in this study, challenging (frustrating) and rewarding and mixed (overlapping) emotions, had both risk and protective factors. This combination demonstrates the conflicting experiences of protective and risk factors that can be present when caretaking for a child with ASD. When more protective factors are present, resilience is enhanced, which results in better health outcomes. However, when there is an increase in risk factors, the health of the individual can be compromised and the risk for poorer physical or psychological outcomes might result.

[Perspectives in Psychiatric care, Vol 53, No. 3 (July 2017): pg. 199-207. DOI. This article is @ [Wiley] and permission has been granted for this version to appear in e-Publications@Marquette. [Wiley] does not grant permission for this article to be further copied/distributed or hosted elsewhere without the express permission from [Wiley].] 
The findings of this qualitative study found more risk factors than protective factors expressed by caregivers of persons with ASD. This indicates a greater need to understand and to deal with the risk factors as well as to enhance the protective factors when fostering resiliency in caregivers of persons with ASD. In fact, nurses are in a strategic position to help caregivers of persons with ASD to enhance their protective factors in order to buffer the effects of the risk factors. One of the protective factors identified by caregivers in this study was "acceptance." Acceptance is "the ability to tolerate what one might regard as an unpleasant behavior of a relative with disorder, with some understanding of the deeper meaning of that behavior and an appreciation of its value and importance" (Zauszniewski et al., 2015, p. 134). Acceptance Training Intervention (ATI) is recommended to help caregivers accept their child's diagnosis (McDonald, Zauszniewski, Bekhet, DeHelian, \& Morris, 2011), which in turn will improve both the caregivers' quality of life and the child's challenging behaviors.

Lack of resources is a risk factor identified by caregivers in this study. Therefore, resourcefulness training interventions are recommended to empower caregivers/parents of persons with ASD by helping them to use their personal resourcefulness (self-help) and social resourcefulness (help-seeking behaviors; Bekhet \& Zauszniewski, 2014), which in turn will reduce their stress (risk factor) and improve their acceptance (protective factor). Ultimately, this can have a significant impact on their children's challenging behaviors. Caregivers could be taught about how to rely on family and friends when unable to function independently (social resourcefulness) and how to reframe the situation positively when faced with challenges (personal resourcefulness).

Increased public awareness about ASD and how to deal with both the family members of persons with ASD and their children is crucial. Also, the study findings indicated the need for social support, which could be carried out through support groups. Another way to offer support to the caregivers would be to create an online resource for the caregivers with the ability to connect to other caregivers. Future studies should incorporate the findings from this study into interventions for caregivers of persons with ASD.

[Perspectives in Psychiatric care, Vol 53, No. 3 (July 2017): pg. 199-207. DOI. This article is @ [Wiley] and permission has been granted for this version to appear in e-Publications@Marquette. [Wiley] does not grant permission for this article to be further copied/distributed or hosted elsewhere without the express permission from [Wiley].] 
One of the limitations of this study was the potential for selection bias based on those having access to the network from which participants were recruited and those who were willing to share their experiences. There is the potential for a lack of representation of caregivers who are overburdened or lacking time due to their responsibilities as a caregiver. However, one of the advantages of using the internet is the ability to recruit a national sample. Another limitation is that the two open-ended questions were part of larger written questionnaires. This, in fact, limits the researchers' abilities to further explore any comments made by the parents and to seek further clarification. Despite its limitations, the findings of the study provide direction toward promoting resiliency in the caregivers of persons with ASD in order to decrease negative health outcomes and increase their quality of life.

\section{Acknowledgments:}

The parent study was funded by the American Psychiatric Nurses Foundation (APNF), research grant number 74614. The authors acknowledge Dr. Norah Johnson and Dr. Jaclene Zauszniewski for their contributions to the quantitative parent study.

\section{References:}

- American Psychiatric Association. (2000). Diagnostic and statistical manual of mental disorders (4th ed.). Washington, DC: Author.

- Marquette University

- Bekhet, A. (2014). Self-assessed health in caregivers of persons with autism: Associations with depressive symptoms, positive cognitions, resourcefulness, and well-being. Perspectives in Psychiatric Care, 50, 210-217.

- Wiley Online Library I

- PubMed I

- Web of Science $\&$ Times Cited: 3 I

- Marquette University

- Bekhet, A. K., Johnson, N. L., \& Zauszniewski, J. A. (2012a). Effects on resilience of caregivers of persons with autism spectrum disorder: The role of positive cognitions. Journal of the American Psychiatric Nurses Association, 18(6), 337-344.

[Perspectives in Psychiatric care, Vol 53, No. 3 (July 2017): pg. 199-207. DOI. This article is (C [Wiley] and permission has been granted for this version to appear in e-Publications@Marquette. [Wiley] does not grant permission for this article to be further copied/distributed or hosted elsewhere without the express permission from [Wiley].] 
NOT THE PUBLISHED VERSION; this is the author's final, peer-reviewed manuscript. The published version may be accessed by following the link in the citation at the bottom of the page.

- CrossRef I

- Web of Science ${ }^{R}$ Times Cited: 14 |

- Marquette University

- Bekhet, A. K., Johnson, N. L., \& Zauszniewski, J. A. (2012b). Resilience in family members of persons with autism spectrum disorder: A review of the literature. Issues in Mental Health Nursing, 33(10), 650-656.

- CrossRef I

- Marquette University

- Bekhet, A., \& Zauszniewski, J. A. (2014). Psychometrics of resourcefulness scale among caregivers of persons with autism spectrum disorders. Western Journal of Nursing Research, 36(5), 685-702.

- CrossRef ।

- PubMed I

- Web of Science ${ }^{\circledR}$ Times Cited: 1 ।

- Marquette University

- Centers for Disease Control and Prevention. (2015). Autism spectrum disorder (ASD). Retrieved from http://www.cdc.gov/ncbddd/autism/signs. html

- Dardas, L. A., \& Ahmad, M. M. (2014). Psychosocial correlates of parenting a child with autistic disorder. Journal of Nursing Research, 22(3), 183-191.

- CrossRef |

- PubMed I

- Web of Science ${ }^{\circledR}$ Times Cited: 5 I

- Marquette University

- Estes, A., Olson, E., Sullivan, K., Greenson, J., Winter, J., Dawson, G., \& Munson, J. (2013). Parenting-related stress and psychological distress in mothers of toddlers with autism spectrum disorders. Brain \& Development, 35(2), 133-138.

- CrossRef I

- PubMed I

- Web of Science ${ }^{\circledR}$ Times Cited: 45 |

- Marquette University

- Fletcher, P. C., Markoulakis, R., \& Bryden, P. J. (2012). The costs of caring for a child with autism spectrum disorder. Issues in Comprehensive Pediatric Nursing, 35(1), 45-69.

- CrossRef I 
NOT THE PUBLISHED VERSION; this is the author's final, peer-reviewed manuscript. The published version may be accessed by following the link in the citation at the bottom of the page.

- PubMed I

- Marquette University

- Foody, C., James, J. E., \& Leader, G. (2014). Parenting stress, salivary biomarkers, and ambulatory blood pressure in mothers of children with autism spectrum disorders. Research in Autism Spectrum Disorders, 8(2), 99-110.

- CrossRef I

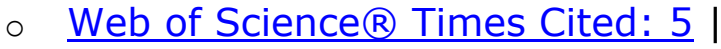

- Marquette University

- Glaser, B. G. (1992). Basics of grounded theory analysis. Mill Valley, CA: Sociology Press.

- Marquette University

- Graneheim, U. H., \& Lundman, B. (2004). Qualitative content analysis in nursing research: Concepts, procedures and measures to achieve trustworthiness. Nursing Education Today, 24, 105-112.

- CrossRef |

- PubMed |

- CAS I

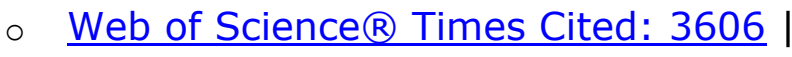

- Marquette University

- Greene, R. R., Galambos, C., \& Lee, Y. (2003). Resilience theory: Theoretical and professional conceptualizations. Journal of Human Behavior and the Social Environment, 8(3), 75-91.

- Marquette University

- Guba, E. G., \& Lincoln, Y. S. (1989). Fourth generation evaluation. Newbury Park, CA: Sage.

- Marquette University

- Hines, M., Balandin, S., \& Togher, L. (2011). Communication and $A A C$ in the lives of adults with autism: The stories of their older parents. Augmentative and Alternative Communication, 27(4), 256-266.

- CrossRef ।

- PubMed I

- Web of Science ${ }^{R}$ Times Cited: 2 I

- Marquette University

- Huang, C., Yen, H., Tseng, M., Tung, L., Chen, Y., \& Chen, K. (2014). Impacts of autistic behaviors, emotional and behavioral problems on parenting stress in caregivers of children with

[Perspectives in Psychiatric care, Vol 53, No. 3 (July 2017): pg. 199-207. DOI. This article is @ [Wiley] and permission has been granted for this version to appear in e-Publications@Marquette. [Wiley] does not grant permission for this article to be further copied/distributed or hosted elsewhere without the express permission from [Wiley].] 
NOT THE PUBLISHED VERSION; this is the author's final, peer-reviewed manuscript. The published version may be accessed by following the link in the citation at the bottom of the page.

autism. Journal of Autism and Developmental Disorders, 44(6), 1383-1390.

- CrossRef I

- PubMed |

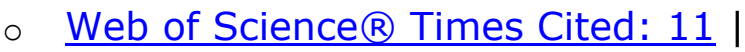

- Marquette University

- Krippendorff, K. (1980). Content analysis. An introduction to its methodology. The Sage Commtext Series. London: Sage

Publications.

- Marquette University

- Lovell, B., Moss, M., \& Wetherell, M. (2012a). The psychosocial, endocrine and immune consequences of caring for a child with autism or ADHD. Psychoneuroendocrinology, 37(4), 534-542.

- CrossRef I

- CAS I

- Web of Science $®$ Times Cited: 29 I

- Marquette University

- Lovell, B., Moss, M., \& Wetherell, M. A. (2012b). With a little help from my friends: Psychological, endocrine and health corollaries of social support in parental caregivers of children with autism or ADHD. Research in Developmental Disabilities, $33(2), 682-687$.

- CrossRef I

- Web of Science ${ }^{\circledR}$ Times Cited: 39 |

- Marquette University

- Luthar, S., Cicchetti, D., \& Becker, B. (2000). The construct of resilience: A critical evaluation and guidelines for future work. Child Development, 71, 543-562.

- Wiley Online Library I

- PubMed I

- $\underline{\text { WAS I }}$

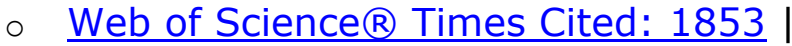

- Marquette University

- McDonald, P. E., Zauszniewski, J. A., Bekhet, A., DeHelian, L., \& Morris, D. (2011). The effect of acceptance training on psychological and physical health outcomes in elders with chronic conditions. Journal of National Black Nurses Association, 22(2), 11-19.

- Marquette University 
NOT THE PUBLISHED VERSION; this is the author's final, peer-reviewed manuscript. The published version may be accessed by following the link in the citation at the bottom of the page.

- National Autism Association. (2014). Autism fact sheet. Retrieved from http://nationalautismassociation.org/resources/autism-factsheet/

- Rutter, M. (1987). Psychosocial resilience and protective mechanisms. American Journal of Orthopsychiatry, 57, 316331.

- Wiley Online Library I

- PubMed I

- $\underline{\text { CAS I }}$

- Web of Science ${ }^{\circ}$ Times Cited: 1539 |

- Marquette University

- Safe, A., Joosten, A., \& Molineux, M. (2012). The experiences of mothers of children with autism: Managing multiple roles. Journal of Intellectual \& Developmental Disability, 37(4), 294302. doi:10.3109/13668250.2012.736614

- CrossRef |

- PubMed |

- Web of Science $®$ Times Cited: 18 |

- Marquette University

- Samadi, S. A., \& McConkey, R. (2014). The impact on Iranian mothers and fathers who have children with an autism spectrum disorder. Journal of Intellectual Disability Research, 28(3), 243254.

- Wiley Online Library I

- Web of Science $®$ Times Cited: 7 I

- Marquette University

- Smith-Osborne, A. (2007). Life span and resiliency theory: A critical review. Advances in Social Work, 8(1), 152-168.

- Marquette University

- Struebert, H. J., \& Carpenter, D. R. (1999). Qualitative research in nursing: Advancing the humanistic imperative. Philadelphia, PA: Lippincott Williams \& Wilkins.

- Marquette University

- Tozer, R., Atkin, K., \& Wenham, A. (2013). Continuity, commitment and context: Adult siblings of people with autism plus learning disability. Health \& Social Care in the Community, 21(5), 480-488.

- Wiley Online Library |

[Perspectives in Psychiatric care, Vol 53, No. 3 (July 2017): pg. 199-207. DOI. This article is (C [Wiley] and permission has been granted for this version to appear in e-Publications@Marquette. [Wiley] does not grant permission for this article to be further copied/distributed or hosted elsewhere without the express permission from [Wiley].] 
NOT THE PUBLISHED VERSION; this is the author's final, peer-reviewed manuscript. The published version may be accessed by following the link in the citation at the bottom of the page.

- PubMed I

- Web of Science $\AA$ Times Cited: 3 I

- Marquette University

- Zauszniewski, J. A., Bekhet, A., \& Suresky, J. (2015). Indicators of resilience in family members of adults with serious mental illness. Psychiatric Clinics of North America, 38(1), 131-146.

- CrossRef I

- PubMed |

- Web of Science ${ }^{\circledR}$ Times Cited: 1 |

- Marquette University

- Zhou, T., \& Yi, C. (2014). Parenting styles and parents' perspectives on how their own emotions affect the functioning of children with autism spectrum disorders. Family Process, 53(1), 67-79.

- Wiley Online Library I

- PubMed I

- Web of Science ${ }^{\circledR}$ Times Cited: 4 I

- Marquette University

\section{Related content}

